\title{
Sharia Hotel Management Strategy in Facing Covid-19 Pandemic (A Case Study of Namira Sharia Hotel Yogyakarta)
}

\author{
Priska Auliana Darojat ${ }^{1}$, Dr. Ahim Abdurahim ${ }^{2 *}$ \\ ${ }^{1,2}$ Faculty of Economic and Business Universitas Muhammadiyah Yogyakarta \\ *Corresponding author. Email: Ahimabdurahim@gmail.com
}

\begin{abstract}
This study aims to explore the strategy of Islamic hotels to maintain financial performance in the face of the Covid-19 pandemic. The object of research is the Namira Islamic hotel in Yogyakarta. The preliminary data analysis results showed an increase in losses at the beginning of the pandemic, and subsequently, the losses decreased after the company implemented a strategy to deal with the Covid-19 pandemic. This research used a qualitative approach. The data used included summaries of financial reports, digital photo documentation, transcripts of interviews with hotel manager informants, front office, and hotel guests. The data generation methods used documentation, observation, and interviews. The data were analyzed in three stages, namely relevance analysis, content analysis, and correlation analysis. The results showed that during the Covid-19 pandemic, Hotel Syariah Namira experienced a decrease in the number of hotel visitors, which affected the hotel's financial performance. To restore financial performance, financial management strategies were carried out, including; (1) Reducing operational costs, (2) Managing human resources, (3) Cooperating with start-ups, and (4) Diversifying products.
\end{abstract}

\section{Keywords: Covid-19, Financial Performance, Pandemic, Sharia Hotel, Strategy}

\section{INTRODUCTION}

Islamic economic development is currently taking an important position in improving economic growth in Indonesia. One of the sectors that provide added value to improving Islamic economic development is the tourism sector. According to [1], the tourism industry is one of the largest and fastest-growing sectors of the economy. With high potential owned by the State of Indonesia, the country ranks two as the largest population of Muslims globally or as many as 209 million Muslims in Indonesia. Halal tourism is a new nickname to the new model implemented and developed by the Indonesian Tourism Agency to fulfill Muslim tourists' demand of the archipelago and abroad.

Special Region of Yogyakarta (DIY) is known as a tourist city with the nickname Jogja Istimewa. The city has three specialties: a cultural center, an education center, and a combat center. These three privileges are the attraction and selling points of tourists. Yogyakarta has many potentials and great opportunities that currently develop several business sectors and invite business people to invest in several regions in Yogyakarta. In this case, the high opportunity in the business segment includes the field of accommodation.

The selection of sharia hotels as temporary housing for Muslim tourists is a form of worship to Allah SWT and a form of effort in distancing ourselves from all the possibilities of negative things that can happen and may cause sin. The appearance of sharia hotel service products is expected to create a high market share. At the end of
2019, a phenomenon galvanized all countries in the world that found a virus quite deadly in china. In fact, on December 31, 2019, a warning was issued by the World Health Organization (WHO) that the virus under research was called the COVID-19 virus.

This virus paralyzes many industrial sectors, including the tourism industry sector. With the emergence of this virus, the government issued a new policy known as Large-Scale Social Restrictions (PSBB). The data obtained by the Tourism Office of DIY inform a decrease in the number of tourists who used hospitality accommodation services. A decrease reached $7.97 \%$ in the use of foreign tourist star hotels or as many as 338,858 tourists in 2019 compared to 368,198 tourists in 2018 . . The emergence of this phenomenon during this pandemic urges business people to create the right strategy to continue to carry out hotel operational activities during the COVID-19 pandemic without performing termination of employment (layoffs) to their employees. Many hotels experience quiet conditions due to the absence of tourist activities that make visitors make reservations for hotel room occupancy. 


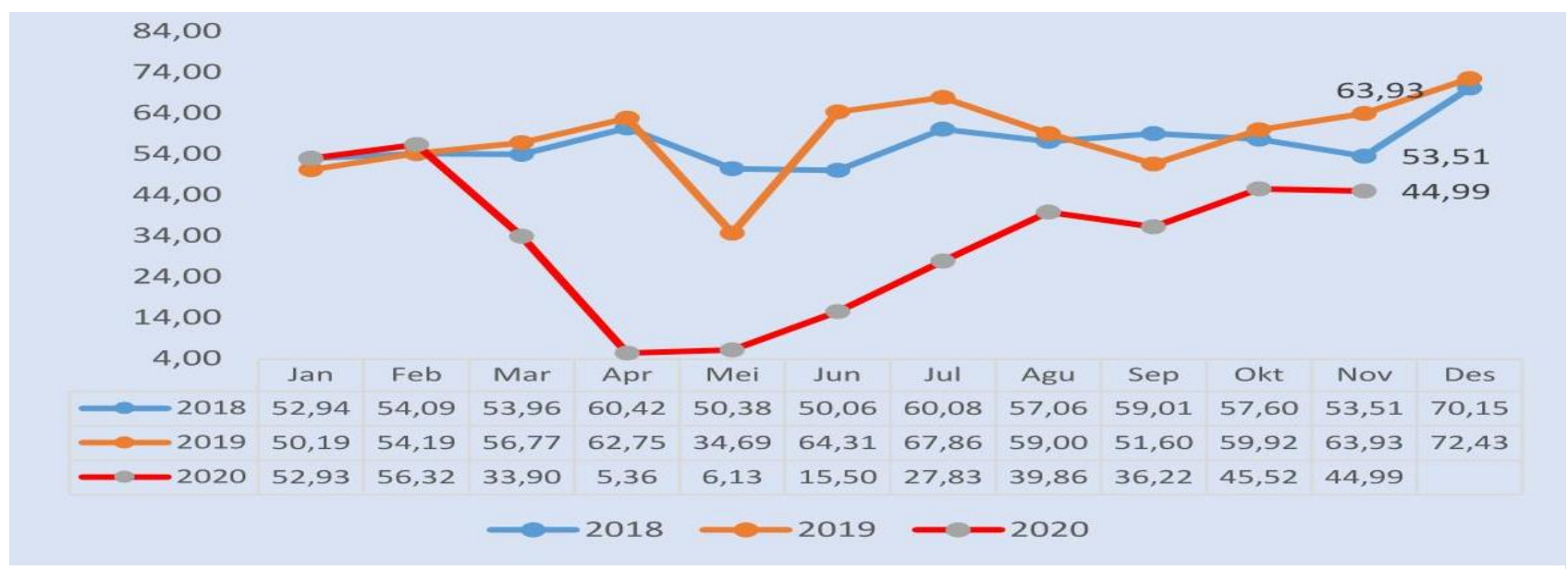

Figure 1. Star Hotel TPK Development in DIY 2018-2020. Source: [2]

Based on the data above, the development of hotel room occupancy rates in the last 3 years experienced a significant decrease in 2020, precisely in March, April and May, due to the issuance of PSBB policies (large-scale social restrictions). The peak decrease occurred in April, reaching $5.36 \%$ occupancy rate of star hotel rooms by 2020 . Based on the background, this study aims to determine how sharia hotels' strategy is implemented during the COVID-19 pandemic. It can be formulated by identifying how the financial performance and management strategy of Namira Hotel Syariah Yogyakarta. In addition, this study also aims to identify the impact felt by Namira Hotel Syariah Yogyakarta during the COVID-19 pandemic.

\section{THEORETICAL FRAMEWORK}

\subsection{Dynamic Capability Theory}

Dynamic capability continuously integrates and reconfirms resources to gain a competitive advantage under changing environments [3]. According to [4], dynamic capabilities are organizational behavior and enterprise strategies in achieving new resource configurations when markets arise, collide, split, evolve, and die.

\subsection{Theory of Sharia Economic Entity}

Sharia economic entity is a unit of the organization or legal entity that conducts a transaction activity in the economic field by applying sharia principles. Components of Sharia economic entities include;

1) Sharia money market

2) Sharia capital market

3) Sharia insurance

4) Sharia banking

5) Sharia microfinance institutions

6) Organization of zakat management

\subsection{Sharia Tourism}

According to [5], Sharia tourism is a tourist demand based on the lifestyle of Muslim tourists during the holidays. Sharia tourism is part of the tourism industry, and its existence is directly adjacent to conventional tourism. According to the National Sharia Council of the Indonesian Ulema Council [6], tourism contains elements under the principles and provisions set or recommended in Islam.

\subsection{Sharia Hotels}

Understanding sharia hotel or halal hotel is one of the hotels that provide halal services to Muslim tourists. This type of hotel serves halal food and drinks. The operation of the entire hotel will also be managed based on Islamic principles [7]. Specifically, the definition of sharia hotel is a hotel that applies Islamic sharia also Islamic regulation into its operational activities [8].

\subsection{Sharia Hotel Management Criteria}

The fatwas set by [6] No.108/DSN-MUI/X/2016 related to sharia hotel management criteria include:

1) Sharia hotels may not provide pornography access facilities and immoral acts

2) Sharia hotels may not provide entertainment facilities that lead to idolatry, immorality, pornography and/or immorality

3) Food and beverages provided by sharia hotels must have been certified halal by MUI

4) Provide adequate facilities, equipment and facilities for the implementation of worship, including purity facilities

5) The manager and employees of the hotel shall wear sharia-compliant clothing

6) Sharia hotels must have guidelines on hotel service procedures to ensure the implementation of hotel services in accordance with sharia principles

7) Sharia hotels are obliged to use the services of Sharia financial institutions in performing service 


\subsection{Financial Performance}

Financial performance is a form of achievement in the financial field derived from operational activities carried out in a certain period. According to [9], it is a description of the state of success of an economic entity or an achievement of activities that have been carried out in a certain period. To improve the stated financial performance, it is necessary to analyze the financial statements.

\subsection{1 $\quad$ Financial Statements}

Analysis of financial statements is urgently needed to measure the company's success. Financial statements can also be said to be a means of communication of parties that have the importance of a position in making decisions. In conducting financial statements analysis, it can be seen through the company's profit and loss statement.

\subsubsection{Profitability Ratio}

Profitability Ratio is a ratio that examines the extent to which an economic entity's ability obtains profit value or profit.

\subsection{COVID-19 Pandemic}

COVID-19 is one of the most contagious diseases and also has a fairly rapid spread. The disease is caused by the acute respiratory syndrome of coronavirus 2 or SARS-Co V2. The earliest cases of emergence came from one of the cities in China, namely Wuhan city. The initial symptoms are the onset of fever with a temperature of $38^{\circ} \mathrm{C}$, tightness in the screening, dry cough, and the worst impact of death in humans. Until the beginning of June 2020, it was confirmed that 34,000 people in Indonesia were affected by the COVID19 virus.

\section{RESEARCH METHODOLOGY}

This research used the descriptive qualitative method. According to [10], qualitative research is the research method used as the main instrument. The type of data in this research was primary data collected without going through intermediaries. The instrument used to gather the data was by conducting interviews, observations, and documentation. The object of this study was Namira Hotel Syariah, located in the Special Region of Yogyakarta. It is publicly known as a Shariah hotel. Meanwhile, the subjects of this study were the management staff, employees, and visitors of Namira Hotel Syariah Yogyakarta.

\section{RESULTS}

\subsection{The Impact of COVID-19 Pandemic on Namira Hotel Syariah Yogyakarta.}

The spread of this virus resulted in much deterioration in the economic sector. The economic sector of the tourism industry has got a big impact from the COVID-19 pandemic. Moreover, the hospitality accommodation business, in this case, is also devastated by COVID-19. The impact of the spread of the COVID-19 virus to the implementation of the
PSBB policy implemented by the central government causes a rapid decrease in the number of guests staying at Namira Hotel Syariah. In this case, the decrease in the number of staying guests refers to the decrease in revenue of Namira Hotel Syariah. On the day before the spread of the COVID19 virus, Namira Hotel Syariah's room rentals are estimated to be 15 rooms rented out per day. Meanwhile, hotel room rental decreased only around 0-3 rooms rented per day during the pandemic. Besides, some changes or modifications to services also occur during the pandemic.

Namira Hotel Syariah Manager provides information regarding losses during 2020.

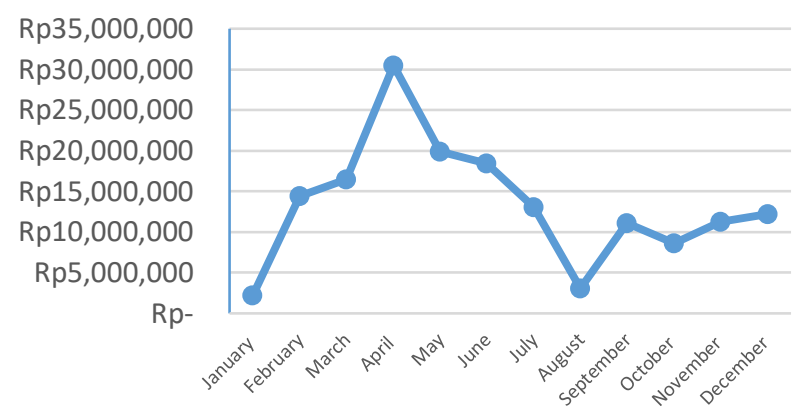

Figure 2. Total losses in 2020

The initial increase in losses began in February, and the peak of the increase in losses incurred by Namira Hotel Syariah occurred in April with a loss of Rp. 30,499,601.52. Based on interviews with hotel managers, this increase in losses occurred at the beginning of the reported spread of COVID-19 in Jogja and the implementation of the PSBB policy that occurred from April to June. However, those who have entered the new normal condition have not been able to restore financial condition like before the spread of the COVID-19 virus.

\subsection{Financial Performance Management Strategy}

\subsubsection{Reducing Operational Costs}

Management of financial aspects relates to the management of hotel operating expenses posts. Namira Hotel Syariah has a strategy to reduce operational costs and make savings on operational costs. It is due to the decrease in the number of hotel rooms rented during the COVID-19 pandemic. Furthermore, the electricity usage saving policy is carried out by arranging the schedule of electricity usage activities by not turning on the lights in all rooms at night. However, some costs can not be reduced, such as internet costs and maintenance costs of hotel equipment.

\subsubsection{Managing Human Resources (HR)}

Human resources are an important aspect of improving and growing a business. In a hospitality business, human resources refer to hotel employees. The human resource management strategy carried out by Namira Hotel Syariah management during the COVID-19 pandemic was to divide 
working hours into two parts, namely day and night shifting and the implementation of health protocols. The division of working hours was carried out to comply with the policy of banning crowds, included in the rules of large-scale social restrictions (PSBB) made by the central government.

\subsubsection{Cooperation with Start-Up}

One aspect of the success of a business is the marketing aspect. During the spread of the COVID-19 virus, Namira Hotel Syariah has been credited with OYO hospitality service start-ups to help with marketing and one of the strategies during the COVID-19 pandemic. OYO's hospitality services are also in collaboration with Traveloka startups. It occurred since, during the COVID-19 pandemic, all social activities conducted face-to-face were diverted online. One form of marketing conducted by OYO during the COVID-19 pandemic was the promotion of discounted rates.

\subsubsection{Modifying Services}

Product diversification is one of the steps to increase revenue or reduce the occurrence of loss risks. During the COVID-19 pandemic, sharia hotels conducted a service modification strategy. In the case before the spread of the COVID-19 virus, staying guests were provided with a free bottled beverage service. A service modification strategy was created by making the cost of consumption of bottled beverages for hotel guests. This strategy aims to minimize cost expenditures during the decrease in revenue at sharia hotels.

\section{CONCLUSION}

\subsection{Conclusion}

Based on the result of this study, it can be concluded that there has been a drastic decrease in the number of hotel visitors, as evidenced by the acquisition of data from the Central Bureau of Statistics DIY and the data on a real condition. During the COVID-19 pandemic, Namira Hotel Syariah continued to operate the hotel by creating management strategies adjustable to pandemic conditions, including:

1) Minimizing electricity costs by saving electricity usage in unused rooms.

2) Managing human resources by sharing working hours with hotel employees to lower costs to avoid layoffs.

3) Collaborating with OYO's media startups to support hotel revenue and make it easier for guests to book hotel rooms during the COVID-19 pandemic conducted online.

4) Modifying non-functional services to reduce the income.

The thing that can inspire other hotels is Islam and humanity's perspective during the COVID-19 pandemic. The hotel maintains employees as well as salaries received during the decrease in revenue. The hotel owner bears all hotel losses during the COVID-19 pandemic.

\subsection{Suggestions}

The Suggestions of this study are as follows:

1) Further research is expected to add more literature review.

2) Further research is expected to interview more respondents.

3) Further research can be conducted on hotels with higher star status.

\subsection{Research Limitations}

The limitations of this study are as follows:

1) Pandemic conditions become one of the limitations to reduce direct meetings with resource persons.

2) Restrictions on financial data information that cannot be provided by the source to researchers or outside parties who are not part of Namira Hotel Syariah

\section{REFERENCES}

[1] M. R. Razalli, S. Abdullah, and M. G. Hassan, "Developing a Model for Islamic Hotels: Evaluating Opportunities and Challenges," Int. J. Islam. Mark. Brand., 2009.

[2] Badan Pusat Statistik, "STATISTIK Perkembangan Pariwisata dan Transportasi Nasional November 2020," Ber. Resmi Stat., no. 110, pp. 1-12, 2021.

[3] D. J. Teece, G. Pisano, and A. Shuen, "Dynamic Capabilities and Strategic Management," Strateg. Manag. J., vol. 18, no. 7, p. 25, 1997.

[4] K. M. Eisenhardt and J. A. Martin, "Dynamic capabilities: What are they?," Strateg. Manag. J., vol. 21, no. 10-11, pp. 1105-1121, 2000, doi: 10.1002/10970266(200010/11)21:10/11<1105::AID-SMJ133>3.0.CO;2-E.

[5] H. T. Alim, A. O. Riansyah, K. Hidayah, and I. Muslim, "YOGYAKARTA," pp. 1-8, 2008.

[6] F. D. MUI, Fatwa Dewan Syariah Nasional-Majelis Ulama Indonesia, vol. 53, no. 9. 2016.

[7] S. Chookaew, O. chanin, J. Charatarawat, P. Sriprasert, and S. Nimpaya, "Increasing Halal Tourism Potential at Andaman Gulf in Thailand for Muslim Country," J. Econ. Bus. Manag., vol. 3, no. 7, pp. 739-741, 2015, doi: 10.7763/joebm.2015.v3.277.

[8] widyarini, "Pengelolaan Hotel Syariah di Yogyakarta," vol. VIII, no. 1, pp. 1-12, 2013.

[9] A. Trianto, “Analisis Laporan Keuangan Sebagai Alat Untuk Menilai Kinerja Keuangan Perusahaan Pada Pt. Bukit Asam (Persero) Tbk Tanjung Enim," Ilm. Ekon. Glob. Masa Kini, vol. 8, no. 03, p. 10, 2017.

[10] Sugiyono, Metode Penelitian Pendidikan Pendekatan Kuantitatif, kualitatif, dan R\&D. Bandung: Alfabeta, 2010. 